\title{
Causes of eosinophilic ascites - A systematic review
}

\author{
LARISA PINTE ${ }^{1}$, CRISTIAN BAICUŞS ${ }^{1,2}$ \\ ${ }^{1}$ Internal Medicine Department, "Colentina" Clinical Hospital, Bucharest, Romania \\ ${ }^{2 "}$ Carol Davila" School of Medicine, Bucharest, Romania
}

\begin{abstract}
Background. In the last years an uprising interest for a relatively unknown entity, eosinophilic ascites (EA), has been recorded.

Our aim is to investigate the potential causes of EA development, as well as clinical, laboratory, endoscopic and radiologic features, management and outcome in these patients.

Methods. The following research was performed on PubMed (MEDLINE) database using the medical subject headings [Mesh] terms "Ascites" AND "Eosinophils".

Results. A total of 284 results, dating from 1962 onwards, were found and abstracts were examined.

131 papers were excluded and the remaining 153 publications, consisting in case reports and series of cases, were analyzed.

From 171 patients with EA, 127 subjects (74\%) had EGE, 17 (10\%) parasitic and fungal infections, 11(7\%) Hypereosinophilic syndrome and 16 patients (9\%) less common diseases (eosinophilic pancreatitis, chronic eosinophilic leukemia, myelofibrosis, T-cell lymphoma, Churg Strauss Syndrome, Systemic lupus erythematosus, Familial paroxysmal polyserositis and Ménétrier's disease). High eosinophil blood count and IgE levels as well as gastrointestinal symptoms are frequent. The diagnosis is based on ascitic fluid analysis, imaging and endoscopic biopsies. Therapy with corticosteroids results in resolution of eosinophilic ascites in almost all patients.

Conclusion. In most cases, in the absence of allergy, parasitic infections, malignancy, hematological disorders, peritoneal tuberculosis, inflammatory bowel disease or autoimmune disease, EA develops as a manifestation of eosinophilic gastroenteritis.
\end{abstract}

Key words: Ascites, Hypereosinophilia, Eosinophilic ascites, Eosinophilic gastroenteritis, Hypereosinophilic syndrome, parasitic infection, systematic review.

\section{INTRODUCTION}

Ascites often appears as a manifestation of various diseases such as cirrhosis, heart failure, neoplasia, tuberculosis or pancreatic disease. Depending on its development mechanism, peritoneal fluid might have various colors (translucent yellow, milk-colored, turbid, bloody, brown) with a SAAG below or above $1.1 \mathrm{~g} / \mathrm{dL}$ and various white blood cell count.

The most common causes of ascites are parenchymal liver disease $(78 \%)$ and malignancy (12\%), followed by cardiovascular disease (5\%) [1].

Eosinophilic ascites (EA) is a rare disorder of unknown etiology, characterized by high eosinophil counts in the peritoneal fluid, reported in both adult and pediatric patients.

We aimed to investigate the potential mechanisms of EA development.

\section{MATERIAL AND METHODS}

The following research was performed on PubMed (MEDLINE) database using the medical subject headings [Mesh] terms "Ascites" AND "Eosinophils".

\section{RESULTS}

A total of 284 results, dating from 1962 onwards, were found and abstracts were examined.

Seventy-six papers without evidence of eosinophilic ascites, twenty nine narrative reviews and later on twenty six studies in whom the inclusion criteria were not EA (13 regarding patients with EGE, 10 parasitic infections and other 3 suggesting alternative diagnostic methods that might be used in subjects with EA) were excluded.

The remaining 153 publications, consisting in case reports and series of cases, were analyzed according to gender, age, allergy history, clinical, laboratory, endoscopic and radiologic features, management and outcome.

Over the last years, an uprising interest regarding eosinophilic ascites was registered, with 13 new reports published in the current year (Fig. 1).

We analyzed 153 publications consisting of case reports and series of cases involving patients 
with eosinophilic ascites, 17 of them followed by a brief narrative review.

Among the analyzed papers 2 of them included animal subjects with gastrointestinal eosinophilic sclerosing fibroplasias [2] and Leiomyosarcoma with paraneoplastic eosinophilia [3].
Among the 171 human subjects described, the age range was from 2 to 76 years at the moment of diagnosis. Of the total subjects, $52 \%$ were females, with a most evident difference in patients between 21 and 40 years, while in those under 20 and over 61 , an equal gender ratio is noticed.

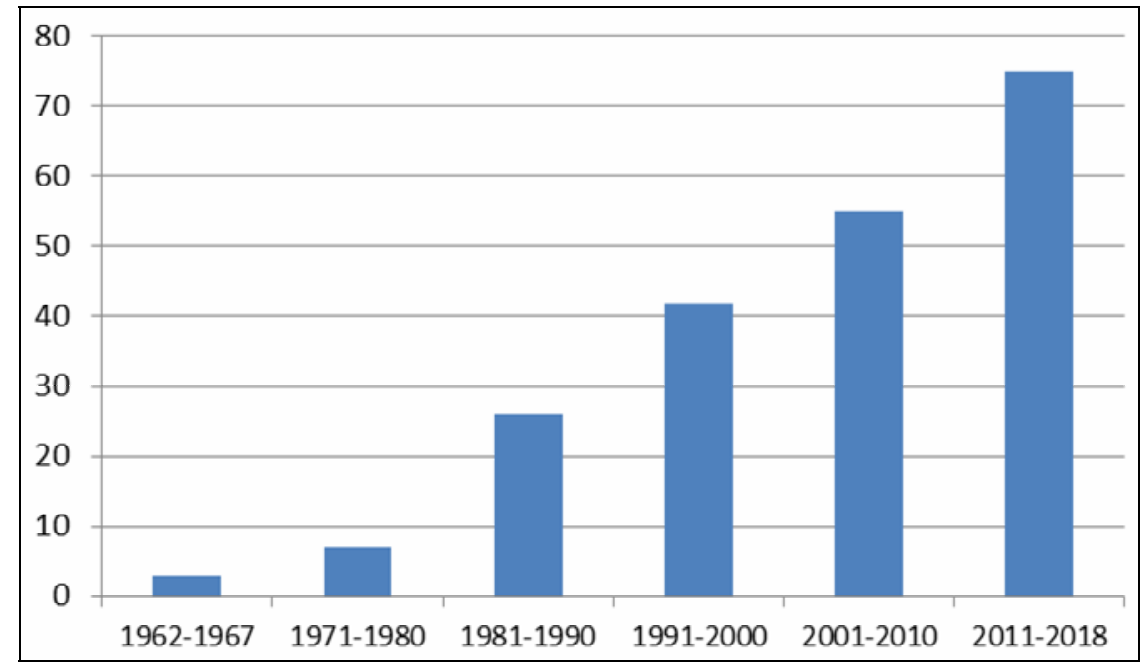

Figure 1. Papers with evidence of EA from 1962 onwards.

\section{Eosinophilic gastroenteritis (EGE)}

In 127 subjects (74\%) eosinophilic ascites represented a manifestation of eosinophilic infiltration in the gastrointestinal tract, also known as eosinophilic gastroenteritis (EGE) or eosinophilic enteritis.

Eosinophilic tissue infiltration may involve any structure of the digestive tract with symptoms varying according to the affected layer.

The gender ratio of 62 males to 65 females (49 to 51\%) suggested that females and males have equal chance to develop EA due to EGE.

In 28 cases $(22 \%)$ history of allergic diseases was reported. With an equal gender ratio, 5 of them [4-8] had nonspecific symptoms, 9 were diagnosed with asthma [9-17], 1 with skin rash [18], while in rest of the patients associations between asthma, allergic rhinitis [19-21], skin rash as well as food, pet and drug allergy were mentioned.

Unlike nonallergic patients, almost all patients with signs of allergy had elevated blood eosinophil count $(93 \%)$ and $\operatorname{IgE}$ levels above range. In the absence of allergy, increased IgE levels and eosinophilia were reported mainly in male patients.

Almost two thirds 106 (83\%) had gastrointestinal symptoms, while the remaining subjects were admitted to the hospital due to increasing abdominal volume (16/21) or constipation $(5 / 21)$. The most common symptom was abdominal pain in 84 patients, associated with nausea and vomiting
(34/84), diarrhea (33/84) and less often with weight loss $(8 / 84)$.

In addition to the symptoms described above, 29 subjects associated less frequent features like constipation (6) [13, 22-26], bloating (1) [27], skin rash (4) [27-30], fever (3) [31-33], edema (2) [3435], malabsorption (1) [36], melena (1) [37], even signs of pyloric stenosis (3) [38-40], intestinal occlusion or subocclusion(6) [41-46], peritonitis secondary to appendicitis (1) [47] and DVT in one patient with acute pancreatitis [48].

Of the cases with documented peritoneal fluid volume (58/127), most (37/58) presented moderate ascites followed by massive (18/58) and mild (3/58) ascites. Several patients, mostly females, associated pleural effusion (17/127), 5 of them bilaterally, and 1 unilateral but massive.

While none of the patients with mild ascites developed pleural effusion, a total of 11 subjects, 7 with moderate ascites and 4 with massive ascites had pleural effusion, probably due to ascitic fluid transfer via transdiaphragmatic lymphatics or diaphragmatic defects. Absolute eosinophil count range in the ascitic fluid was 860 to 13800 per $\mathrm{mm}^{3}$.

The endoscopic evaluation revealed changes in the gastrointestinal mucosa consisting in edema, hyperemia, erosions, ulcerated lesions, mucosal rings, lumen stenosis, nodularity or polyps in $27 \%(35 / 127)$ of the patients. In most of them, endoscopic 
findings were present in multiple segments of the gastrointestinal tract, while 15 patients had single segment involvement, commonly the stomach or duodenum.

Abdominal ultrasonography and/or CT scan revealed besides different grades of ascites, gastrointestinal wall thickening in $49 \%(62 / 127)$ of the patients, occasionally associated with peritoneal infiltration, peritoneal nodules, abdominal lymphadenopathy (1/34) [49] or splenomegaly (1/34). A quarter of the subjects had only small bowel wall thickening.

Multiple endoscopic biopsies from both normal and abnormal gastrointestinal mucosa showed eosinophil-rich infiltrate in both specimens in more than half of the patients with EA and EGE (74/127). Half of the positive biopsies were obtained from a single gastrointestinal segment. $37 \%$ of the patients with GI wall thickening had a single segment involvement, generally small bowel (14/74), stomach $(12 / 74)$ or colon $(8 / 74)$.

In 19 cases, although multiple biopsies were performed, their results revealed normal mucosa. Because of negative biopsy results in the absence of pathological features at abdominal echo, CT scans or endoscopy, in 6 subjects [17-18, 50-53] laparoscopy with peritoneal biopsies provided valuable information to achieve a definite diagnosis. In 3 patients surgery was not performed, and the diagnosis was established according to clinical and biological criteria [33, 54-55].

Two patients with CT scans describing peritoneal involvement $[18,56]$ and another one with gastrointestinal wall thickening [37], underwent surgery and peritoneal fragments from all 3 subjects were sent for histological analysis. In 10 out of 19 cases with endoscopic lesions (1) [34], peritoneal involvement (1) [15], gastrointestinal wall thickening (3) $[49,57-58]$, endoscopic lesions with gastrointestinal wall thickening (1) [59], as well as in peritoneal involvement and gastrointestinal wall thickening association (1) [43], surgery was not performed and definite diagnosis was established on endoscopic and imaging criteria.

In 22 patients $(17 \%)$ besides EA-EGE, other diseases were reported. EA developed in subjects with preexisting conditions such as: aplastic anemia $(1 / 22)$ [60], HIV (1/22) [61], celiac disease (2/22) $[15,62]$, hepatitis B virus infection $(1 / 22)[41]$ and in subjects with hepatitis $C$ virus infection $(2 / 22)$ recently treated with Interferon for 14 or 12 weeks [63-64]. Associations between EGE and autoimmune diseases were described in 3 patients: one with systemic lupus erythematosus [65], one with lupusscleroderma overlap syndrome and heterozygous bthalassemia [57], and another one presenting positive antinuclear antibodies [50].

History of pancreatitis [27], as well as recurrent [66-67], self-limiting [27] and acute pancreatitis [48, 68-69], were reported in 7 patients. In some cases peritoneal nodules $(1 / 22)$ [33], liver involvement $(2 / 22)[31,70]$, eosinophilic dermatitis $(1 / 22)$ and fasciitis (1/22) [71-72] were described. EAEGE also affected women in the post-partum period at 8 and 10 weeks postpartum [28, 34, 73].

A total of 32 subjects underwent surgery,

26 cases for diagnostic laparoscopy, while in 6 patients emergency surgery was performed: appendicectomy (1/6), enterectomy (2/6), subtotal gastrectomy $(3 / 6)$ in order to resolve the acute episode [13, 40, 47, 60, 67, 74].

Most subjects (110/127, 87\%) were successfully treated with corticosteroids, $(95 / 110)$ in monotherapy or associations with other drugs $(15 / 110)$. Corticotherapy was frequently initiated with $40 \mathrm{mg} /$ day of prednisone, but doses below and above were also reported.

In addition to $\mathrm{CS}$, dietary measures were recommended in 5 patients [6, 19, 24, 28, 75]. CS along with treatments for allergies: Montelukast (2) [7, 66], sodium chromoglycate (1) [27], cetirizine (1) [76] and loratadine (1) [42] were also successfully used. Antibiotherapy -Clarithromycin (1) initially $800 \mathrm{mg} /$ day followed by $600 \mathrm{mg} /$ day associated with low dose of CS [54] or cefotaxine (1) [57] was also reported. Budesonide was added in patients with modified endoscopic features (2) $[32,77]$.

A total of 17 subjects did not receive prednisone for various reasons, but received instead ketotifen (1/17) [78], cefmetazole (1/17) [30], budesonide (1/17) [79] and surgical treatment (3/17) avoiding the need of future medication. Gastric resection represented the solution in 2 patients admitted to the hospital with pyloric obstruction $[13,67]$, while enterectomy was performed in a patient with ileal obstruction [74], all with satisfying results at least for short time. Two patients received only dietary restrictions [80-81], while eight (8/17) recovered spontaneously without medical treatment, although 2 of them presented several self-limited relapses.

There were $15(12 \%)$ patients with relapses among those with EA and EGE (Table 1). 12/15 patients experienced a single relapse, more common in the first 3 to 6 months $[16,27,37,82]$, while 
tapering off corticosteroids. Two patients with frequent recurrences, with rapid spontaneous regression, one associating asthma and the other one increased IL5 levels $[17,81]$, did not receive medical treatment at all. Surgery [27, 37], ketotifen
[82], azathioprine [16], sodium chromoglycate and montelukast $[7,66]$ as monotherapy or in combination with corticosteroids were successfully used while treating relapses. Six patients required long-term steroid therapy [29, 40, 53, 83-85].

Table 1

Relapse management in patients with EA and EGE

\begin{tabular}{|c|c|c|c|c|}
\hline Ref. & Initial treatment & $\begin{array}{c}\text { Number of } \\
\text { relapses }\end{array}$ & Period until relapse & Solution \\
\hline [37] & $\mathrm{CS}$ & 1 & 3 months ( intestinal pseudo-obstruction) & surgery \\
\hline [82] & $\mathrm{CS}$ & 1 & 4 months & Ketotifen \\
\hline [16] & $\mathrm{CS}$ & 1 & 4 months & \begin{tabular}{|l|} 
Azathioprine \\
\end{tabular} \\
\hline [27] & Sodium chromoglycate & 1 & 6 months & surgery, CS and Sodium chromoglycate \\
\hline [66] & CS and Montelukast & 1 & 1 year & CS and Montelukast again \\
\hline [17] & - & 2 & 2 episodes during a 4 year period & Resolved spontaneously each time \\
\hline [83] & $\mathrm{CS}$ & 1 & 4 years ( repeated $\mathrm{Ab}$ administration) & $\mathrm{CS}$ \\
\hline [81] & - & 4 & 4 episodes during a 4 year period & Resolved each time spontaneously \\
\hline [40] & Gastrectomy & 1 & 5 years & $\mathrm{CS}$ \\
\hline [53] & $\mathrm{CS}$ & 1 & When stopping CS & CS $(5 \mathrm{mg})$ on alternate days \\
\hline [7] & $\mathrm{CS}$ & 1 & while tapering off CS & Montelukast added \\
\hline [54] & $\mathrm{CS}$ & 2 & while tapering off CS & $\begin{array}{l}\mathrm{CS} \text { and clarithromycin first } 800 \mathrm{mg} / \text { day, } \\
\text { then } 600 \mathrm{mg} \text { /day }\end{array}$ \\
\hline [84] & $\mathrm{CS}$ & 1 & $\mathrm{Nd}$ & intermittent courses of CS \\
\hline [85] & $\mathrm{CS}$ & 1 & $\mathrm{Nd}$ & CS dependency \\
\hline [29] & $\mathrm{CS}$ & 1 & $\mathrm{Nd}$ & CS (8mg) \\
\hline
\end{tabular}

\section{Parasitic and fungal infections}

A total of 17 cases of EA, 16 associated with parasitic infection and 1 with fungal infection, were identified. Six types of parasites were associated with EA development: Toxocariasis (6 cases) [8691], Strongyloides stercoralis (5 cases) [92-96], Giardia (1 case) [97], Trichuris trichiura (1 case) [98], Ascaris (1 case) [99], Enterobius vermicularis (1 case) [100]. In one patient parasitic etiology [101] was assumed based on therapeutic response to Albendazole administration. Only one case of fungal infection with Coccidioides immitis was reported [102].

With no significant gender difference and age range below 40 years, $70 \%$ (12/17) of patients presented hypereosinophilia and 3 of them associated increased IgE levels.

Clinical manifestations included abdominal pain $(9 / 17)$ and diarrhea $(9 / 17)$ in most of the subjects, followed by vomiting (4/17), weight loss (3/17) and dysphagia (1/17) as well as signs of cardiac involvement with endomyocardial fibrosis in a patient with Strongyloidiasis. Moderate ascites was present in most of the patients (15/17) and associated with pleural effusion in one.

Endoscopy revealed signs of gastritis and duodenitis in 4 patients, 2 with toxocariasis [88, 90],
1 with strongyloidiasis [93] and 1 with trichiuriasis [98].

Gastrointestinal wall thickening was observed in 6 cases, involving stomach and small bowel in 1 case of trichiuriasis [98], small bowel and colon in 1 case of enterobiasis [100], stomach in 1 case of ascariasis [99], while patients with coccidioidomycosis [102], strongyloidiasis [93] and toxocariasis [88] had only duodenal wall thickening.

Microscopic eosinophilic infiltration of the GI tract was present in subjects with toxocariasis (3) $[86,88,90]$, strongyloidiasis (1) [93], enterobiasis (1) [100], and in 1 patient with trichuriasis in which biopsy specimen of the stomach included a female Trichuris trichiura covered by inflammatory cells [98].

Initially 4 cases were misdiagnosed as EGE due to eosinophilic infiltration in the GI tract and treated with CS, but in the end, all patients received specific treatment with Albendazole, Ivermectin, Pyrantel pamoate or Fluconazole, with a good outcome.

\section{Hypereosinophilic syndrome (HES)}

Hypereosinophilic syndrome, a myeloproliferative disorder, was diagnosed in 11 patients with ages between 11 and 48, mostly females (54\%). 
Although all patients had increased eosinophil blood count, history of asthma (2/11) and elevated $\operatorname{IgE}$ levels $(2 / 11)$ were reported only in several patients.

Half of the patients (6/11) had abdominal pain, 2 nausea and vomiting [103-104], 3 diarrhea [103, 105-106], 1 weight loss, while others associated signs of cardiac [107] and nervous system [108] involvement.

Abdominal ultrasonography revealed moderate ascites in most cases except for 2 patients who developed mild [103] and large [108] peritoneal effusion. Only one subject with HES associated pleural effusion [108].

Although endoscopic evaluation showed gastroduodenitis [109] and ileal hyperemia [103] in 2 patients, and CT scan revealed small bowel wall thickening [103-104] in other 2 cases, random endoscopic biopsies showed eosinophilic GI infiltration in 5 cases; colon involvement was noticed in 2 cases [104, 110], stomach in 1 [108], small bowel in 1 case [109] and both esophagus and colon in another one [103].

Of the 11 patients with HES, 7 had single organ involvement: (4/11) gastrointestinal [103, 105, 110-111], (1/11) pulmonary [112], (1/11) cardiac [107] or (1/11) pancreatic [106] and the diagnosis was confirmed by bone marrow biopsy. In other 3 cases, GI involvement was associated with: cardiac and later on gallbladder involvement [104], eosinophilic cholecystitis due to a common bile duct stricture [109], but also with pulmonary, pleuro-pericardial and central nervous system involvement [108]. Besides a case of Budd-Chiari syndrome associated with HES, subcutaneous nodules and positive FIP1L1-PDGFRA gene were reported [113] (Table 2).

Most of the patients were treated with prednisone, while some of them received ketotifen (1), budesonide (1) or CS associated with hydro- xyurea (1). Two cases of relapse were reported [104-105].

\section{Less common diseases}

A total of 16 cases of EA without EGE, HES or parasitic infection were reported. Two publications described EA associated with pancreatic cancer [114] and secondary to taxol-induced hypersensitivity in a patient treated for ovarian cancer [115] but there was not enough data to analyze the cases. Pathologies associated with EA in the remaining 14 patients, mostly females, with ages between 9 and 76 years are listed in the table below (Table 3 ).

GI symptoms such as abdominal pain (6/14), nausea, vomiting (2/14) and diarrhea (1/14) were present in 6 patients. All patients had normal $\mathrm{IgE}$ level, despite the personal history of asthma (1/14) or rhinitis $(1 / 14)$.

Hypereosinophilia was present in subjects with eosinophilic pancreatitis [116], eosinophilic peritonitis [117], chronic eosinophilic leukemia [118-119], Churg Strauss Syndrome [120], Systemic lupus erythematosus [121] and Ménétrier's disease [122]. Four patients developed bilateral pleural effusion, one of them with pleural mesothelioma [123].

Abdominal CT revealed peritoneal thickness in a patient with T-cell lymphoma [124], unilateral diaphragm thickening in a patient with pleuroperitoneal mesothelioma, abdominal lymphadenopathy with mild hepatosplenomegaly in a patient with SLE and small bowel wall thickening in a child with pathological endoscopic findings and microscopic signs of eosinophilic gastric infiltration diagnosed with Ménétrier's disease.

The mechanism responsible for EA development in patients with catamenial pneumothorax [125], granulocytic sarcoma [126], Familial paroxysmal polyserositis [127] and spontaneous bacterial peritonitis with E. coli [128], remains unclear.

Table 2

Organ involvement in patients with HES

\begin{tabular}{|l|l|}
\hline$[103][105][110][111]$ & GI involvement $(4 / 11)$ \\
\hline$[112]$ & Pulmonary involvement $(1 / 11)$ \\
\hline$[106]$ & Pancreatic involvement $(1 / 11)$ \\
\hline$[107]$ & Cardiac involvement $(1 / 11)$ \\
\hline$[104]$ & GI, cardiac and later on cholecystic involvement $(1 / 11)$ \\
\hline$[109]$ & GI $(\mathrm{s}+\mathrm{sb})$ and eosinophilic cholecystitis with common bile duct stricture $(1 / 11)$ \\
\hline$[113]$ & Budd-Chiari syndrome associated with HES, subcutaneous nodules FIP1L1 and PDGFRA gene mutations $(1 / 11)$ \\
\hline$[108]$ & $\begin{array}{l}\text { HES with stomach wall involvement, interstitial lung disease, pleural and pericardial effusion. central } \\
\text { nervous system involvement (Grand mal epilepsy) }(1 / 11)\end{array}$ \\
\hline $\mathrm{s}+\mathrm{sb}=$ stomach and small bowel \\
\hline
\end{tabular}


Table 3

Patients with eosinophilic ascites without EGE, HES or parasitic infection

\begin{tabular}{|c|c|c|c|c|c|}
\hline Ref. & Gender & GI symptoms & Other findings & Diagnosis & Means of diagnosis \\
\hline$[125]$ & $\mathrm{F}$ & no & Weight loss & catamenial pneumothorax & \\
\hline$[120]$ & M & no & $\begin{array}{l}\text { dyspnoea, purpura, edema, } \\
\text { symmetrical sensory peripheral } \\
\text { neuropathy }\end{array}$ & Churg Strauss Syndrome & skin biopsy \\
\hline$[117]$ & $\mathrm{F}$ & $\begin{array}{l}\text { Abdominal pain, } \\
\text { nausea, vomiting, } \\
\text { diarrhea }\end{array}$ & no & eosinophilic peritonitis & Ascites \\
\hline$[118]$ & M & chos & spinal cord compression, trisomy 8 & $\begin{array}{l}\text { chronic eosinophilic leukemia } \\
\text { (extradural eosinophilic } \\
\text { chloroma) }\end{array}$ & Bone marrow biopsy \\
\hline [119] & $\mathrm{F}$ & no & hepatomegaly & chronic eosinophilic leukemia & Liver biopsy \\
\hline [116] & $\mathrm{F}$ & Abdominal pain & pancreatic pseudocyst & eosinophilic pancreatitis & nd \\
\hline$[124]$ & M & Abdominal pain & no & T-cell lymphoma & $\begin{array}{l}\text { Peritoneal FNA CT } \\
\text { guided }\end{array}$ \\
\hline$[126]$ & $\mathrm{F}$ & Abdominal pain & jaundice & granulocytic sarcoma & Ascites \\
\hline$[128]$ & M & Abdominal pain & no & $\begin{array}{l}\text { spontaneous bacterial } \\
\text { peritonitis }(E \text {. coli })\end{array}$ & Ascites \\
\hline$[123]$ & M & no & back pain & $\begin{array}{l}\text { pleural and peritoneal } \\
\text { mesothelioma }\end{array}$ & $\begin{array}{l}\text { parietal pleura } \\
\text { (thoracoscopy) }\end{array}$ \\
\hline$[121]$ & $\mathrm{F}$ & no & $\begin{array}{l}\text { fever, skin lesion, } \\
\text { thrombocytopenia, anemia }\end{array}$ & Systemic lupus erythematosus & $\begin{array}{l}\text { Coombs, ANA +, } \\
\text { DNAdc }\end{array}$ \\
\hline$[127]$ & $\mathrm{F}$ & no & no & $\begin{array}{l}\text { Familial paroxysmal } \\
\text { polyserositis }\end{array}$ & $\begin{array}{l}\text { response to } \\
\text { colchicine }\end{array}$ \\
\hline$[122]$ & $\mathrm{F}$ & $\begin{array}{l}\text { Abdominal pain, } \\
\text { nausea, vomiting }\end{array}$ & edema & Ménétrier's disease & Gastric biopsy \\
\hline [129] & nd & no & no & myelofibrosis & autopsy \\
\hline
\end{tabular}

Skin, bone marrow, liver, peritoneal, pleural, and gastric biopsies as well as autoimmune markers and peritoneal fluid analysis along with autopsy [129] in one case were performed to obtain a definite diagnosis.

\section{Additional findings not included in the analysis}

Although excluded from our analysis, EA was reported in 23 studies, 13 of them, including human subjects with EGE [130-142] and 10 of them both animal and human subjects with parasitic infection [143-152].

In nine retrospective studies on 6 to 71 patients with EGE, EA prevalence was between 4 and $88 \%$. When endoscopic biopsies failed to provide a diagnosis, peritoneal fluid analysis, showing high eosinophil count, on its own $(9 / 235)$ or combined with radiologic imaging (4/235) was considered in order to confirm EGE.

One retrospective study involving 10 Asian pediatric patients (mean age 10.8) with EGE and ascites, revealed that in all cases, subjects developed EA as a mark of EGE subserosal layer involvement [134]. With an equal gender ratio, and high eosinophil blood count and endoscopic biopsies revealing eosinophilic infiltrate in all of the patients,
$60 \%$ had history of allergy, $100 \%$ abdominal pain, followed by vomiting (30\%) and diarrhea (20\%). CS were successfully used in all subjects.

Regarding studies involving human subjects with parasitic infections, EA developed mostly in patients with anisakiasis $(63 \% ; 78 \%)$ [149-150], followed by those with strongyloidiasis $(60 \%)$ [148], paragonimiasis (32\%) [143] and less frequent in those with ancylostomiasis (9\%) [151].

In addition aspects regarding novel approach in the diagnosis of patients with EA of unknown origin or EA associated with EGE, such as Natural orifice transluminal endoscopic surgery (NOTES) ultrasound-guided percutaneous fine-needle biopsy, are also proposed [45, 153-154].

\section{DISCUSSION}

Eosinophilic ascites has been reported mostly in patients with EGE, HES and parasitic infections (Fig. 2).

Eosinophilic gastroenteritis (EGE) is an inflammatory gastrointestinal disease affecting both children and adults, mainly males. Eosinophilic infiltration 
is present in one or more areas of the GI tract, without other organ involvement and in the absence of an identified cause of eosinophilia.

Hypereosinophilic syndrome (HES) is a myeloproliferative disorder characterized by persistent eosinophilia, associated with damage to multiple organs (Table 4).

Whether associated with EGE, HES, parasitic infection or less common diseases females (52\%) and males have almost equal chance to develop EA.

\section{4 publications}

\section{1 excluded \\ - 76 without evidence of EA \\ - 29 narrative reviews \\ - 26 studies (EA was not the inclusion criteria)}

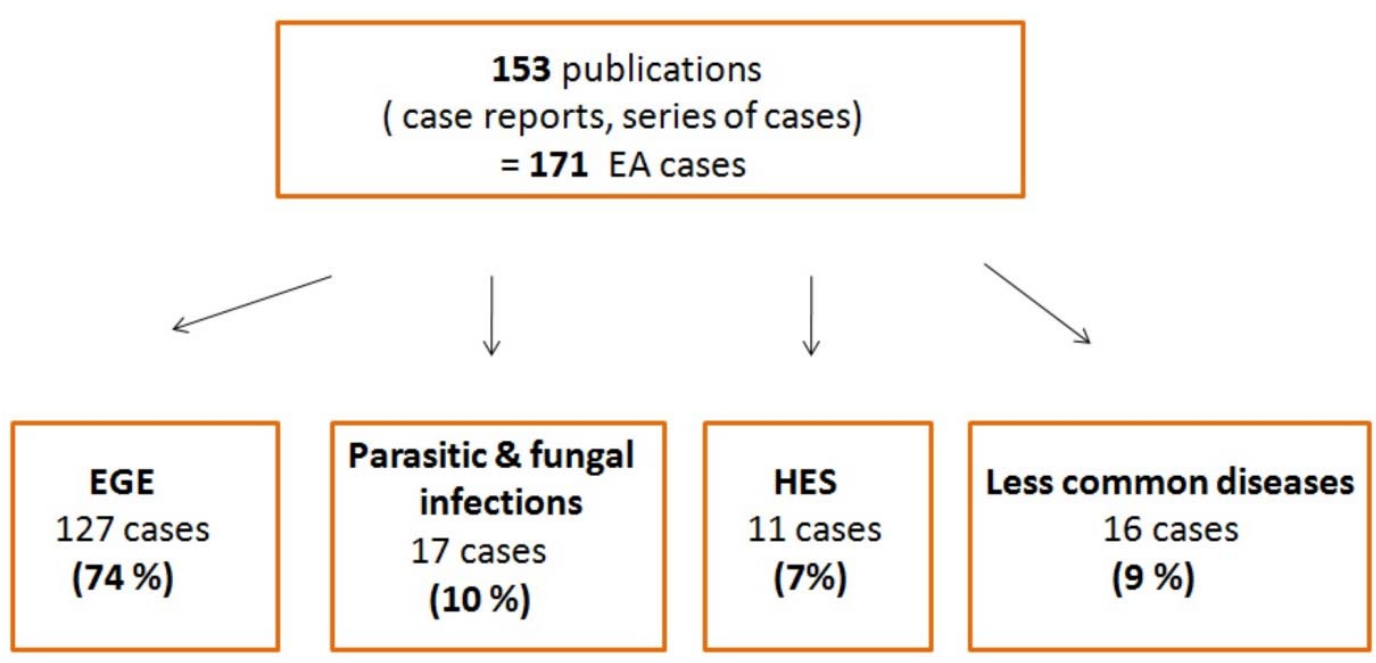

Figure 2. Causes of EA development.

Table 4

Hypereosinophilic Syndrome diagnostic criteria (Chusid, 1975)

\begin{tabular}{|l|l|}
\hline 1 & Sustained blood eosinophilia greater than $1500 / \mathrm{mm}^{3}$ for longer than 6 months \\
\hline 2 & No identifiable etiology for eosinophilia \\
\hline 3 & Signs and symptoms of organ involvement \\
\hline
\end{tabular}

The elevated eosinophile blood count is found mainly in EA patients with HES (100\%), EGE (74\%) and parasitic infection (70\%). Besides, subjects with increased eosinophilia may be diagnosed with less frequent pathologies such as eosinophilic pancreatitis, eosinophilic peritonitis, chronic eosinophilic leukemia, Churg Strauss Syndrome and Ménétrier's disease. Some studies reported eosinophilia during chronic pancreatitis, without evidence of eosinophilic pancreatic tissue infiltrate [155-156].
While referring to $\mathrm{IgE}$ levels, there was no significant difference between EA patients with EGE (19\%), HES (18\%) and parasitosis (19\%).

Patients with EA often describe nonspecific gastrointestinal symptoms such as abdominal pain, nausea/vomiting, diarrhea and occasionally weight loss.

In patients with EA and EGE, clinical features vary according to the involved gastrointestinal layer and site [157] (Table 5).

Table 5

Eosinophilic gastroenteritis classification (Klein, 1970)

\begin{tabular}{|l|l|c|}
\hline Layer involved & \multicolumn{1}{|c|}{ Clinical features } & {$[157]$} \\
\hline mucosal & $\begin{array}{l}\text { abdominal pain, nausea, vomiting, diarrhea, blood loss in the stool, iron deficiency anemia, malabsorption, } \\
\text { protein-losing enteropathy }\end{array}$ & $57 \%$ \\
\hline muscle & bowel wall thickening with obstructive gastrointestinal symptoms & $30 \%$ \\
\hline subserosal & bloating, exudative ascites, higher peripheral eosinophile counts & $13 \%$ \\
\hline
\end{tabular}


We compared the prevalence of digestive symptoms (abdominal pain, nausea/vomiting, diarrhea) in patients with EGE, HES, parasitic infections and in those with less common pathologies.

Patients with EA and EGE (83\%), HES $(81 \%)$ and parasitosis $(70 \%)$ described at least one gastrointestinal symptom. Abdominal pain and nausea or vomiting appears to be more common in patients with EGE $(66 \% ; 31 \%)$, while diarrhea is reported mostly in patients with parasitic infections (53\%). Weight loss was also reported in some patients, frequently in those with parasitic infections.

Abdominal ultrasound, endoscopic examination and sometimes $\mathrm{CT}$ scan are current investigations performed in patients presenting with gastrointestinal symptoms.

Beside routine blood tests and peritoneal fluid analysis, stool analysis for ova and parasites along with serology should be performed to exclude parasitic infection.

Studies performed on animal subjects revealed that parasitic infection caused marked absolute eosinophilia, and focal eosinophil infiltrate in the gastrointestinal layers, mimicking eosinophilic gastroenteritis [145, 148, 150-151, 158]. In humans, Toxocara, Strongyloides stercoralis, Giardia, Trichuris trichiura, Ascaris and Enterobius vermicularis are responsible for most parasitic infections, while infections due to Setaria species and Cestoda were reported only in animals.

Upper and lower endoscopy often revealed nonspecific lesions such as edema, hyperemia, erosions, ulcerated lesions, mucosal rings, lumen stenosis, nodularity or polyps, mostly in EA patients with EGE.

Regarding patients with EA-EGE, biopsies from abnormal mucosa showed in most cases eosinophilic mucosal infiltration $(77 \%, 27 / 35)$. $80 \%(28 / 35)$ of the patients with endoscopic lesions associated imaging findings of gastrointestinal wall thickening. Of the total 62 patients with gastrointestinal wall thickening observed in at least one GI segment, in $72 \%$ microscopic eosinophilic mucosal infiltration was confirmed.

Although EGE diagnosis is confirmed by histological examination, radiological features suggesting an inflammatory process, combined with typical clinical manifestations, may lead to the correct diagnosis [159]. CT findings are also helpful for assessing the extent and location of the disease, while abdominal ultrasound can represent a suitable follow-up method.

In patients with high suspicion of gastroenteritis involving muscular and subserosal layers as well as small bowel segments, other investigations such as Ultrasound-guided percutaneous fine-needle biopsy [45] or capsule endoscopy and doubleballoon enteroscopy [160] may be performed as an alternative to laparoscopy to achieve a definite diagnosis.

Dosing IL5 and IL2 receptor levels, in the blood and peritoneal fluid, might have predictive value for relapses, while ascitic fluid level of complements C3 or C4 [154] might help rule out liver disease origin in EA patients.

EA-EGE was also described in patients with autoimmune diseases: scleroderma, SLE, polymyositis, dermatomyositis [57, 65] and celiac disease [15, 62]. EA in postpartum females, mainly associated with EGE, was also reported in three cases $[28,34$, 73].

Pancreatitis associated with EGE is believed to be due to eosinophilic infiltration leading to edema, fibrosis and distortion in the ampulla and periampullary duodenum [66].

Some authors suggest that diffuse eosinophilic gastroenteritis, along with EA, could be isolated manifestations of the hypereosinophilic syndrome $[107,112,161]$. In EA patients with elevated eosinophile blood count, screening for other organ involvement and hematological evaluation, including PDGFRA-FIP1L1 gene mutation, bone marrow aspirate and biopsy, should be performed to rule out HES. Although less frequent, peritoneal tuberculosis should also be ruled out [162].

While patients with parasitosis and hematological disorders such as $\mathrm{T}$ cell lymphoma and chronic eosinophilic leukemia require specific treatment, in patients with food allergy dietary treatment should be the first therapeutic measure, especially in children. Corticosteroids are currently the best line of EA treatment in both patients with EGE and HES.

Enteric coated budesonide [32, 79, 163] and mast cell stabilizer medications, such as Ketotifen [78], represented alternatives to prednisone treatment in EA patients with EGE and HES, while leukotriene receptor antagonists (Montelukast, Sodium Chromoglycate) [7, 27, 66], histamine antagonist (Loratadine, Cetirizine) [42, 76] and immunosuppressive medication (Azathioprine) [16] were used in relapse treatment (Fig. 3). 


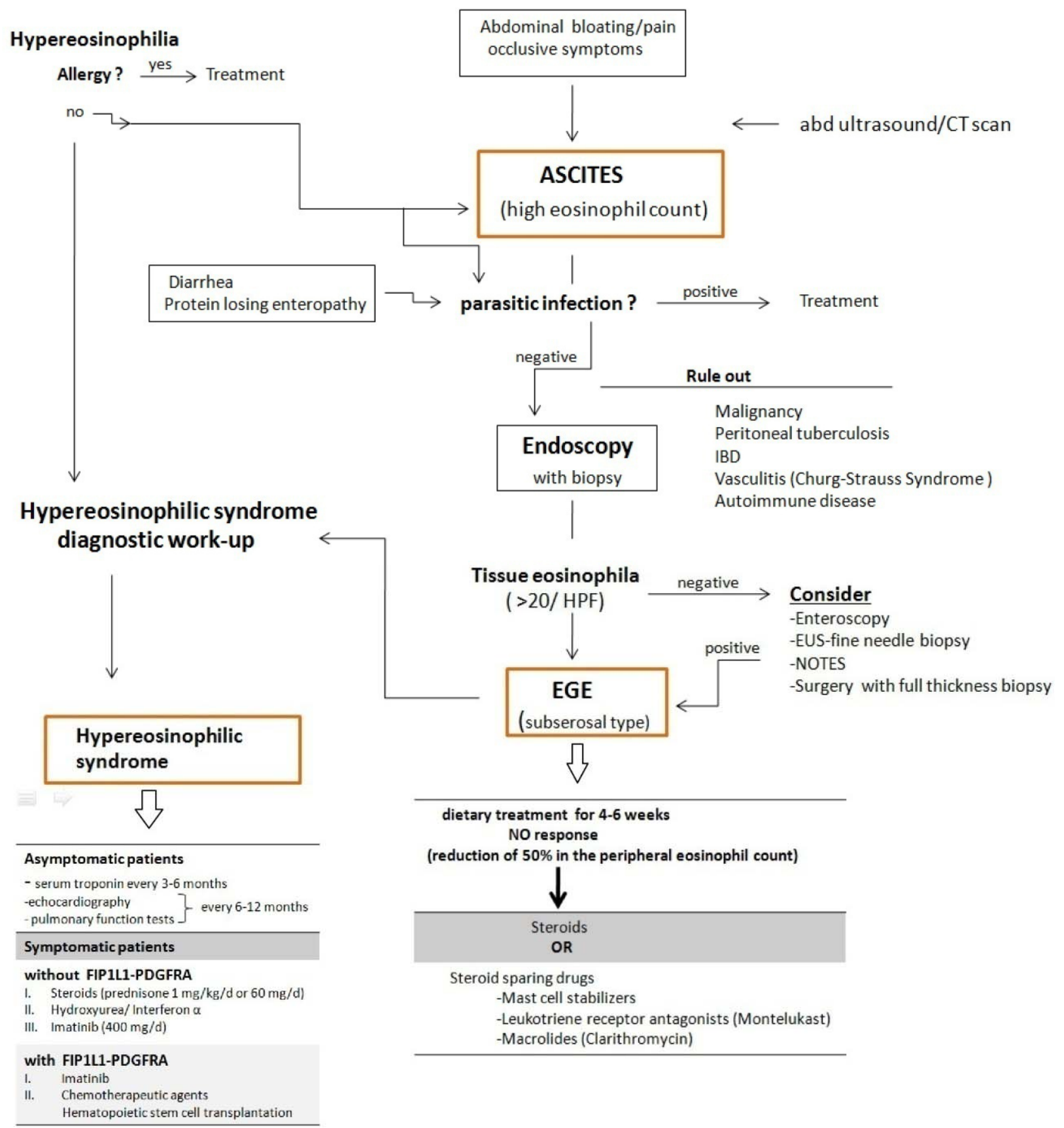

Figure 3. EA diagnostic and treatment algorithm (based on our findings and British Society for Hematology Guidelines, Guideline for the investigation and management of eosinophilia).

\section{CONCLUSION}

In most cases, in the absence of allergy, parasitic infections, malignancy, hematological disorders, peritoneal tuberculosis, inflammatory bowel disease, autoimmune disease, eosinophilic ascites develops as a manifestation of EGE.

Although laparoscopic serosal biopsies are required for a definite diagnosis, ascitic fluid eosinophilia, radiological findings such as gastrointestinal wall thickening, peritoneum infiltration and response to steroid treatment indirectly confirm the diagnosis of EGE.

Therapy with corticosteroids results in resolution of eosinophilic ascites in almost all patients at least for a short time.

Declaration of interest: The authors state there is no coflict of interest.

Abbreviations: EA: eosinophilic ascites; EGE: eosinophilic gastroenteritis; GI: gastrointestinal; HES: Hypereosinophilic syndrome; SLE: Systemic lupus erythematosus; SAAG: serum-ascites albumin gradient; IgE: immunoglobulin E; IL: interleukin; CS: corticosteroids. 
Introducere. În ultimii ani se constată un interes în creştere faţă de o patologie relativ nestudiată, ascita eozinofilică. Scopul lucrării este să investigheze cauzele care duc la apariția acestei patologii, analizând caracteristici clinice, biologice, endoscopice, imagistice, precum şi tratamentul şi evoluția ulterioară a pacienților cu ascită eozinofilică.

Materiale şi metode. Au fost introduşi în motorul de căutare al bazei de date PubMed termenii ,Ascites” AND ,Eosinophils”.

Rezultate. Din cele 284 de articole publicate din 1962 până în prezent, 131 au fost excluse pentru că nu au intrunit criteriile de includere. Din totalul de 171 de pacienți cu ascită eozinofilică, colectați din cele 153 cazuri şi serii de cazuri publicate, 127 (74\%) au fost diagnosticați cu gastroenterită eozinofilică, 17 (10\%) cu infecții parazitare sau fungice, 11 (7\%) cu Sindrom hipereozinofilic, iar $16(9 \%)$ cu patologii mai puțin frecvente ( pancreatită eozinofilică, leucemie cronică eozinofilică, mielofibroză, limfom cu celulă T, Sindrom Churg Strauss, lupus eritematos sistemic, febră mediteraneană familială şi boală Ménétrier). Hipereozinofilia, valorile crescute ale IgE şi manifestările digestive sunt caracteristici frecvent întâlnite la pacienții cu ascită eozinofilică. Diagnosticul se stabileşte în urma analizei lichidului de ascită, a modificărilor radiologice şi endoscopice, iar tratamentul constă în coticoterapie, cu evoluție favorabilă în majoritatea cazurilor.

Concluzii. De cele mai multe ori, în lipsa alergiei, infecției parazitare, neoplaziei, tuberculozei intestinale, bolilor inflamatorii intestinale şi patologiilor hematologice sau autoimune, ascita eozinofilică este o manifestare in cadrul gastroenteritei eozinofilice.

Correspondence to: Larisa Pinte, M.D., Internal Medicine Department, "Colentina” Clinical Hospital, 19-21 Stefan cel Mare Boulevard, sect. 2, 020125 Bucharest, Romania

E-mail: larissa.0806@yahoo.com

\section{REFERENCES}

1. AHMAD J., FRIEDMAN S.L., DANCYGIER H., Ascites, Mount Sinai Expert Guides-Hepatology. 2014, pp. 210.

2. KAMBE N., OKABE R., OSADA H., OGAWA M., KISHIMOTO M., FUKUSHIMA R. et al., A case of feline gastrointestinal eosinophilic sclerosing fibroplasia limited to the mesentery, J. Small Anim. Pract., 2018.

3. FEWS D., SCASE T.J., BATTERSBY I.A., Leiomyosarcoma of the pericardium, with epicardial metastases and peripheral eosinophilia in a dog, J. Comp. Pathol., 2008, 138 (4) 224-228.

4. AGRAWAL S., VOHRA S., RAWAT S., KASHYAP V., Eosinophilic ascites: A diagnostic and therapeutic challenge, World J. Gastrointest. Surg., 2016, 8 (9) 656-659.

5. YEP GAMARRA V., MATOS NOVA A., ALDAVE HERRERA A., Eosinophilic gastroenteritis with ascites: clinical case report, Rev. Gastroenterol. Peru, 31 (2) 173-7.

6. LOPES AZEVEDO R.J., PINTO J., RIBEIRO H., PEREIRA F., LEITÃO C., CALDEIRA A. et al., Eosinophilic enterocolitis: An exceedingly rare entity, GE Port. J. Gastroenterol., 2018, 25 (4) 184-188.

7. QUACK I., SELLIN L., BUCHNER N.J., THEEGARTEN D., RUMP L.C., HENNING B.F., Eosinophilic gastroenteritis in a young girl - long term remission under Montelukast, BMC Gastroenterol., 2005, 5, p. 24.

8. MCNABB P.C., FLEMING C.R., HIGGINS J.A., DAVIS G.L., Transmural eosinophilic gastroenteritis with ascites, Mayo Clin. Proc., 1979, 54 (2) 119-22.

9. SETIA N., GHOBRIAL P., LIRON P., Eosinophilic ascites due to severe eosinophilic ileitis, Cytojournal, 2010,7 (1) 19.

10. SIMONIUK U., MCMANUS C., KIIRE, Eosinophilic gastroenteritis - a diagnostic enigma, BMJ Case Rep., 2012, pp. bcr 1220115436-bcr1220115436.

11. DOGGUI M.H., BEN YAGHLENE L., MOHSNI S., MESTIRI A., BOUGUASSAS W., KSANTINI I., Eosinophilic gastroenteritis with ascites: a case report, Tunis. Med., 2008, 86 (6) 600-3.

12. GUPTA P., SINGLA R., KUMAR S., SINGH N., NAGPAL P., KAR P., Eosinophilic ascites. A rare presentation of eosinophilic gastroenteritis, J. Assoc. Physicians India, 2012, 60, 53-5.

13. LEAL R., FAYAD L., VIEIRA D., FIGUEIREDO T., LOPES A., CARVALHO R. et al., Unusual presentations of eosinophilic gastroenteritis: two case reports, Turk. J. Gastroenterol., 2014, 25 (3) 323-9.

14. JARRY J., PEYCRU T., SHEKHER M., A rare cause of ascites, Gastroenterology, 2011, 140 (4) 1149, 1364.

15. AMIRAV I., ROSENTHAL E., BENTUR L., GLEICH G.J., NAVEH Y., Coexistence of celiac disease and eosinophilic gastroenteropathy, J. Pediatr. Gastroenterol. Nutr., 2001, 33 (2) 200-1. 
16. MÉNDEZ SÁNCHEZ I.M., RIVERA IRIGOÍN R., UBIÑA AZNAR E., VERA RIVERO F.M., FERNÁNDEZ PÉREZ F., NAVARRO JARABO J.M. et al., Distinct clinical presentations of a single medical entity: eosinophilic enteritis, Gastroenterol. Hepatol., 2007, 30 (1) 19-21.

17. JENSS H., PLAUTH M., GARTNER H.V, Eosinophilic gastroenteritis with ascites, Dtsch. Med. Wochenschr., 1986,111 (25) 984-7.

18. SOLIS-HERRUZO J.A., DE CUENCA B., MUNOZ-YAGUE M.T., Laparoscopic findings in serosal eosinophilic gastroenteritis. Report of two cases, Endoscopy, 1988, 20 (4) 152-3.

19. CAGLAR E., SEZGIN CAGLAR A., GOKTURK S., DOBRUCALI A., A case of eosinophilic gastroenteritis with ascites, Case Rep. Med., 2015, p. 971607.

20. LOURENCO L.C., HORTA D.V., REIS J., Eosinophilic ascites: uncommon presentation of eosinophilic gastroenteritis in a young adult male, GE Port. J. Gastroenterol., 2017, 24, (4) 206-208.

21. TAI Y.G., LIU J.D., LIN K.Y., CHANG J.G., WANG C.K., SIAUW C.P. et al., Eosinophilic gastroenteritis with eosinophilic ascites: report of a case, J. Formos. Med. Assoc., 1990, 89 (10) 901-4.

22. THIELSEN P., RASHID S., KLARSKOV L.L., Eosinophilic ascites is a rare presentationpart of eosinophilic gastroenteritis, Ugeskr. Laeger, 2013, 175 (22) 1577-8.

23. MALEKI N., KALANTAR HORMOZI M., BAHTOUEE M., TAVOSI Z., MOSALLAI POUR H., TAGHIYAN JAMALEDDIN KOLAII S.S., Eosinophilic ascites and duodenal obstruction in a patient with liver cirrhosis, Case Rep. Gastrointest. Med., 2014, p. 928496.

24. NEHME F., KISANG G., GREEN M., TOFTELAND N., Abdominal pain and ascites: not always related to portal hypertension, Cureus, 2016, 8 (10) e812.

25. HRGOVIC Z., BUKOVIC D., HIRS I., MRCELA M., KARELOVIC D., HRGOVIC I. et al., Diffuse eosinophilic gastroenteropathy with pleural effusion and ascites, Med. Arh., 2006, 60 (6) Suppl. 1, 57-9.

26. HIRASHIMA Y., KITAJIMA K., SUGI S., KAGAWA K., MURAKAMI K., FUJIOKA T. et al., Eosinophilic gastroenteritis in the esophagus, stomach, and small intestine in a patient with a choking feeling in the esophagus, Nihon Shokakibyo Gakkai Zasshi, 2007, 104 (5) 660-5.

27. SHEIKH R.A., PRINDIVILLE T.P., PECHA R.E., RUEBNER B.H., Unusual presentations of eosinophilic gastroenteritis: case series and review of literature, World J. Gastroenterol., 2009, 15 (17) 2156-61.

28. KHALIL H. JOSEPH M., Eosinophilic ascites: a diagnostic challenge, BMJ Case Rep., 2016, p. bcr2016216791.

29. LEVEQUE L., MICHIELS C., COLLET E., JOUVE J.L., LORCERIE B., LAMBERT D., Eosinophilic ascites and urticaria, La Rev. Med. interne, 1998, 19 (5) 334-7.

30. MIYAMOTO T., SHIBATA T., MATSUURA S., KAGESAWA M., ISHIZAWA Y., TAMIYA K., Eosinophilic gastroenteritis with ileus and ascites, Intern. Med., 1996, 35 (10) 779-82.

31. ZHOU H.-B., CHEN J.-M., DU Q., Eosinophilic gastroenteritis with ascites and hepatic dysfunction, World J. Gastroenterol., 2007, 13 (8) 1303-5.

32. LOMBARDI C., SALMI A., PASSALACQUA G., An adult case of eosinophilic pyloric stenosis maintained on remission with oral budesonide, Eur. Ann. Allergy Clin. Immunol., 2011, 43 (1) 29-30.

33. BULJEVAC M., UREK M.C., STOOS-VEIC T., Sonography in diagnosis and follow-up of serosal eosinophilic gastroenteritis treated with corticosteroid, J. Clin. Ultrasound, 2005, 33 (1) 43-6.

34. HEPBURN I.S., SRIDHAR S., SCHADE R.R., Eosinophilic ascites, an unusual presentation of eosinophilic gastroenteritis: A case report and review, World J. Gastrointest. Pathophysiol., 2010, 1 (5) 166-70.

35. WOZNIAKOWSKA-GESICKA T., PLANETA-MALECKA I., WISNIEWSKA M., CZKWIANIANC E., KALUZYNSKI A., SUSKI S., Eosinophilic gastroenteritis, Rocz. Akad. Med. Bialymst., 1995, 40 (3) 532-7.

36. SIMMONS W.W., WARREN R.E., Eosinophilic pleural effusion associated with recovery from viral hepatitis A, J. Clin. Gastroenterol., 1994, 19 (2) 143-5.

37 JAIMES-HERNANDEZ J., ARANDA-PEIRERA P., MELENDEZ-MERCADO C.I., Eosinophilic enteritis in association with systemic lupus erythematosus, Lupus, 2009, 18 (5) 452-6.

38. LEVINSON J.D., RAMANATHAN V.R., NOZICK J.H., Eosinophilic gastroenteritis with ascites and colon involvement, Am. J. Gastroenterol., 1977, 68 (6) 603-7.

39. CHOU C.H., SHIN J.S., WU M.H., CHOW N.H., LIN X.Z., Eosinophilic gastroenteritis with esophageal involvement, J. Formos. Med. Assoc., 1996, 95 (5) 403-5.

40. SALAZAR F., SALAZAR F., Eosinophilic gastroenteritis, Rev. Gastroenterol. Peru, 15 (2) 176-80.

41. HSU Y.Q., LO C.Y., A case of eosinophilic gastroenteritis, Hong Kong Med. J. = Xianggang yi xue za zhi, 1998, 4 (2) $226-228$.

42. SALKIC N.N., MUSTEDANAGIC-MUJANOVIC J., JOVANOVIC P., ALIBEGOVIC E., Enhanced therapeutic response with addition of loratadine in subserosal eosinophilic gastroenteritis, Med. Glas. (Zenica)., 2013, 10 (1)178-82.

43. OTTOBRELli A., LAGGET M., ARRIGONI A., GINDRO T., BOSIO C., BALBO G. et al., Eosinophilic gastroenteritis and ascites. Clinical case, Minerva Gastroenterol. Dietol., 37 (2) 131-4.

44. WIESNER W., KOCHER T., HEIM M., BONGARTZ G., CT findings in eosinophilic enterocolitis with predominantly serosal and muscular bowel wall infiltration, JBR-BTR, 2002, 85 (1) 4-6.

45. SLEIMAN I., VILLANACCI V., PELIZZARI G., BETTINI L., BALESTRIERI G.P., Ultrasound guided percutaneous fineneedle biopsy in a case of eosinophilic gastroenteritis, J. Med. Liban., 46 (2) 100-2.

46. DUVALL C.P., COLEMAN W.A., Conservative management of eosinophilic infiltration of the gastrointestinal tract. Report of a case, Am. J. Dig. Dis., 1967, 12 (1) 107-9.

47. TRAN D., SALLOUM L., TSHIBAKA C., MOSER R., Eosinophilic gastroenteritis mimicking acute appendicitis, Am. Surg., 2000, 66 (10) 990-2. 
48. JAVID BHAT K., BHAT S., DUTT K., GUPTA S., JEELANI SAMOON H., Chronic diarrhea, eosinophilic ascites, acute pancreatitis and deep venous thrombosis: A case report, Casp. J. Intern. Med., 2014, 5 (3) 182-5.

49. SMITH T.R., SCHMIEDEBERG P., FLAX H., WU E., Nonmucosal predominantly serosal eosinophilic enteritis. A case report, Clin. Imaging, 1990, 14 (3) 235-8.

50. KODAN P., SHETTY M.A., PAVAN M.R., KARIAPPA A., MAHABALA C., Acute eosinophilic ascites: an unusual form of an unusual case, Trop. Doct., 2015, 45 (1) 39-41.

51. BOUHMIDI A., LORENTE POYATOS R., ROMERO CARA P., IBÁÑEZ MARTÍN J.J., CASADO CABALLERO F., QUINTERO FUIENTES D. et al., Eosinophilic enteritis as a rare cause of ascites, Gastroenterol. Hepatol., 2003,26 (8) $480-1$.

52. TEPATONDELE T., MAILlEUX P., FIASSE R., PRINGOT J., MACQ J., FERRANT A. et al., Eosinophilic gastroenteritis. Observation of a case with diffuse lesions and involvement of peritoneal serosa, Acta Gastroenterol. Belg., 48 (5) 501-8.

53. TROUNCE J.Q., TANNER M.S., Eosinophilic gastroenteritis, Arch. Dis. Child., 1985, 60 (12) 1186-8.

54. OHE M., HASHINO S., Successful treatment of eosinophilic gastroenteritis with clarithromycin, Korean J. Intern. Med., 2012, 27 (4) $451-4$.

55. TANG K.T., LEE M.J., YANG W., Pediatric eosinophilic gastroenteritis: report of one case, Acta Paediatr. Taiwan, 41 (5) 273-5.

56. DE MATOS BRASIL A.A.G., BEZERRA L.N.P., BRUNO E. L.A., CARVALHO D.R., DE OLIVEIRA P.L.P., LEITE R.L.T., Eosinophilic gastroenteritis with malabsorption, acute intestinal obstruction, ascites and pleural effusion: A case report and review of literature, Gastroenterol. Res., 2013, 6 (6) 233-236.

57. ASLANIDIS S., PYRPASOPOULOU A., SOUFLERIS K., KAZANTZIDOU E., DOUMA S., Eosinophilic enteritis with ascites in a patient with overlap syndrome, Case Rep. Med., 2009, p. 734206.

58. TO Y., OGAWA C., OTOMO M., ARAI Y., SANO Y., TASHIRO Y. et al., A case of eosinophilic gastroenteritis complicated with ileus and ascites collection, Arerugi, 1999, 48 (1) 50-5.

59. ANDRIULLI A., RECCHIA S., VALENTE G., PERA A., VERME G., Endoscopic ultrasonography in eosinophilic infiltration of gastric wall, Ital. J. Gastroenterol., 1990, 22 (3) 129-32.

60. TSUJIO G., AOMATSU N., WANG E., YAMAKOSHI Y., NAGASHIMA D., HIRAKAWA T. et al., A case of eosinophilic enteritis needed to distinguish from a tumor of the small intestine, Gan To Kagaku Ryoho., 2016, 43 (12) 1863-1865.

61. BAGASARAWALA I., MANIAR J.K., MANKED A., RUNDERAWALA H., Eosinophilic ascites-rarest presentation of a rare disease, eosinophilic gastroenteritis, J. Assoc. Physicians India, 2017, 65 (9) 93-94.

62. LIM D. N.F., WILKINS A., HORTON L.E., AHMAD I., LO POLITO C., PHILLIPS C., Eosinophilic gastrointestinal disorder in coeliac disease: a case report and review, Case Rep. Gastrointest. Med., 2012, p. 124275.

63. HIRANO G., FUKUNAGA A., SOHDA T., KUNIMOTO H., YOTSUMOTO K., SAKURAI K. et al., Eosinophilic gastroenteritis in a patient with chronic hepatitis $C$ who received treatment with pegylated interferon, Clin. J. Gastroenterol., 2012, 5 (2) $127-30$.

64. KAKUMITSU S., SHIJO H., AKIYOSHI N., SEO M., OKADA M., Eosinophilic enteritis observed during alpha-interferon therapy for chronic hepatitis $C$, J. Gastroenterol., 2000, 35 (7) 548-51.

65. BARBIE D.A., MANGI A.A., LAUWERS G.Y., Eosinophilic gastroenteritis associated with systemic lupus erythematosus, J. Clin. Gastroenterol., 38 (10) 883-6.

66. BAEK M.S., MOK Y.M., HAN W.-C., KIM Y.S., A patient with eosinophilic gastroenteritis presenting with acute pancreatitis and ascites, Gut Liver, 2014, 8 (2) 224-7.

67. LYNGBAEK S., ADAMSEN S., ARU A., BERGENFELDT M., Recurrent acute pancreatitis due to eosinophilic gastroenteritis. Case report and literature review, JOP, 2006, 7 (2) 211-7.

68. LE CONNIE D., NGUYEN H., Eosinophilic gastroenteritis, ascites, and pancreatitis: a case report and review of the literature, South. Med. J., 2004, 97 (9) 905-6.

69. CHANDRASEKAR T.S., GOENKA M.K., LAWRENCE R., GOKUL B.J., MURUGESH M., MENACHERY J., An unusual case of ascites, Indian J. Gastroenterol., 2012, 31 (4) 203-7.

70. HAUSER M., AINSWORTH M., DITZEL H.J., Eosinophilic gastroenteritis with liver involvement and ascites, Ugeskr. Laeger, 1988, 150 (24) 1477-9.

71. CHA J.M., IL LEE J., JOO K.R., SHIN H.P., Eosinophilic gastroenteritis with eosinophilic dermatitis, Yonsei Med. J., 2010,51 (1) 145-7.

72. MATSUURA T., YAMADE M., MATSUSHITA N., KAWASAKI S., TERAI T., UOTANI T. et al., A case of eosinophilic gastroenteritis accompanied with fasciitis of the extremities, Nihon Shokakibyo Gakkai Zasshi, 2011, 108 (3) 444-50.

73. SINGH P.S., KUSHWAHA S.R.S., Eosinophilic ascitis, an unusual presentation of eosinophilic gastro-enteritis, J. Indian Med. Assoc., 2014, 112 (2) 117-8, 123.

74. YUN M.Y., CHO Y.U., PARK I.S., CHOI S.K., KIM S.J., SHIN S.H. et al., Eosinophilic gastroenteritis presenting as small bowel obstruction: a case report and review of the literature, World J. Gastroenterol., 2007, 13 (11) 1758-60.

75. ELLIOTT J.A., MCCORMACK O., TCHRAKIAN N., CONLON N., RYAN C.E., LIM K.T. et al., Eosinophilic ascites with marked peripheral eosinophilia: a diagnostic challenge, Eur. J. Gastroenterol. Hepatol., 2014, 26 (4) 478-84.

76. MING G., BO Y., LI-PING Y., Eosinophilic gastroenteritis with ascites in a child, Indian Pediatr., 2015, 52 (8) $707-8$.

77. LIM K.C., TAN H.K., RAJNAKOVA A., VENKATESH S.K., Eosinophilic gastroenteritis presenting with duodenal obstruction and ascites, Ann. Acad. Med. Singapore, 2011, 40 (8) 379-81.

78. SHI L., JIA Q.-H., LIU F.-J., GUAN H., JIANG Z.-Y., Massive hemorrhagic ascites: A rare presentation of eosinophilic gastroenteritis, World J. Clin. cases, 2018, 6 (7) 156-160.

79. TAŞ A., ÇELIK H., An unusual cause of ascites in a young patient, Turk. J. Gastroenterol., 2013, 24 (1) 79-80.

80. PFAFFENBACH B., ADAMEK R.J., BETHKE B., STOLTE M., WEGENER M., Eosinophilic gastroenteritis in food allergy, Z. Gastroenterol., 1996, 34 (8) 490-3. 
81. TAKAHASHI T., NAKAMURA K., NISHIKAWA S., TSUYUOKA R., SUZUKI A., MURAKAMI M. et al., Interleukin-5 in eosinophilic gastroenteritis, Am. J. Hematol., 1992, 40 (4) 295-8.

82. SALGUEIRO P., MAGALHÃES R., LAGO P., Cramping pain and eosinophilic ascites: what is the diagnosis?, Gastroenterology, 2013, 144 (7) 1353, 1577.

83. OHNUMA-KOYAMA A., YOSHIDA T., TAKAHASHI N., AKEMA S., TAKEUCHI-KASHIMOTO Y., KUWAHARA M. et al., Malignant peritoneal mesothelioma with a sarcomatoid growth pattern and signet-ring-like structure in a female $f 344$ rat, J. Toxicol. Pathol., 2013, 26 (2) 197-201.

84. KRAVIS L.P., SOUTH M.A., ROSENLUND M.L., Eosinophilic gastroenteritis in the pediatric patient, Clin. Pediatr. (Phila)., 1982, 21 (12) 713-7.

85. BARABINO A.V., CASTEllanO E., GANDUlliA P., TORRENTE F., GUIDA A., MAGNANO G.M., Chronic eosinophilic ascites in a very young child, Eur. J. Pediatr., 2003, 162 (10) 666-8.

86. TAU A.H., VIZCAYCHIPI K.A., CABRAL D.H., MARADEI J.L., FERREYRA A.H., SAN SEBASTIÁN E.I., Eosinophilic ascites secondary to toxocariasis, Acta Gastroenterol. Belg., 78 (3) 336-9.

87. CRUZ A.T., FRANKLIN G.Y., KAPLAN S.L., Toxocariasis causing eosinophilic ascites, Pediatr. Infect. Dis. J., 2008, 27 (6) 563-4.

88. CHIRA O., BADEA R, DUMITRASCU D., SERBAN A., BRANDA H., AL HAJJAR N. et al., Eosinophilic ascites in a patient with toxocara canis infection. A case report, Rom. J. Gastroenterol., 2005, 14 (4) 397-400.

89. SCHAFFELLNER S., WAGNER D., SEREINIGG M., JAKOBY E., KNIEPEISS D., STIEGLER P. et al., First case of Toxocara eosinophilic ascites after combined pancreas and kidney transplantation, Am. J. Transplant, 2010, 10 (12) 2727.

90. GUHA M., JARIWALA S., JINJOLOVA N., MAZER N., REVERE E., RISKA P. et al., Toxocariasis presenting as eosinophilic ascites in a post-partum female, J. Parasit. Dis., 2015, 39 (2) 284-6.

91. VAN LAETHEM J.L., JACOBS F., BRAUDE P., VAN GOSSUM A., DEVIERE J., Toxocara canis infection presenting as eosinophilic ascites and gastroenteritis, Dig. Dis. Sci., 1994, 39 (6) 1370-2.

92. SHUKLA S., CHAUHAN R., WADHWA S., SEHGAL S., SINGH S., Strongyloides stercoralis hyperinfection causing eosinophilic ascites, Diagn. Cytopathol., 2015, 43 (9) 731-3.

93. JARIWALA S., LANGMAN Y., BENSON A.A., WOLF E., MOSS J., ZHU C.C. et al., Strongyloidiasis presenting as eosinophilic ascites, Ann. Trop. Med. Parasitol., 2011, 105 (4) 335-8.

94. LAWATE P., SINGH S.P., Eosinophilic ascites due to Strongyloides stercoralis, Trop. Gastroenterol., 26 (2) 91-2.

95. ALIZADEH-SANI Z., VAKILI-ZARCH A., KIAVAR M., BAHADORIAN B., NABAVI A., Eosinophilic endomyocardial fibrosis and Strongyloides stercoralis: A case report, Res. Cardiovasc. Med., 2013, 2 (2) 104-5.

96. LAMBROZA A., DANNENBERG A.J., Eosinophilic ascites due to hyperinfection with Strongyloides stercoralis, Am. J. Gastroenterol., 1991, 86 (1) 89-91.

97. TURAN I., ZENGIN M., MUSOGLU A., AYDIN A., Giardia lamblia infection as a possible cause of eosinophilic ascites and enterocolitis, Acta Gastroenterol. Belg., 72 (2) 265-6.

98. HONG S.-T., LIM H.-S., KIM D.H., KIM S.-J., A case of gastroenteritis associated with gastric trichuriasis, J. Korean Med. Sci., 2003, 18 (3) 429-32.

99. EBISAWA M., SHICHIJO M., ENDO H., SHIMODA H., MIURA K., SAITO H. et al., Phenotypic analysis of hypodense eosinophils derived from ascites of a patient with ascariasis, Int. Arch. Allergy Immunol., 107 (1-3) 346-7.

100. MACEDO T., MACCARTY R.L., Eosinophilic ileocolitis secondary to Enterobius vermicularis: case report, Abdom. Imaging, 25 (5) 530-2.

101. ONCU K., YAZGAN Y., KAPLAN M., TANOGLU A., KUCUK I., BERBER U. et al., An extremely uncommon case of parasitic infection presenting as eosinophilic ascites in a young patient, Case Rep. Gastroenterol., 2011, 5 (1) 139-43.

102. ALAVI K., ATLA P.R., HAQ T., SHEIKH M.Y., Coccidioidomycosis Masquerading as Eosinophilic Ascites, Case Rep. Gastrointest. Med., 2015, p. 891-910.

103. FRANCIS F.F., KULICH S.M., HASHASH J.G., Diarrhea, ascites, and eosinophilia, Gastroenterology, 2016,150 (4) e6-8.

104. DE CARPI J.M., RIVES S., PRADA F., VAREA V., Eosinophilic ascites as the first sign of idiopathic hypereosinophilic syndrome in childhood, J. Clin. Gastroenterol., 2007, 41 (9) 864-5.

105. RIMBROT S., BENNETT M., KOMOROVSKI M., LEVY Y., Eosinophilic ascites as a presenting symptom of the hypereosinophilic syndrome, Harefuah, 2001, 140 (6) 471-2, 567.

106. BELlAICHE G., FONTAINE H., CHOUDAT L., LUSINA D., LEY G., SLAMA J. L., Pancreatic involvement, ascites and diarrhea in idiopathic hypereosinophilic syndrome, Gastroenterol. Clin. Biol., 1997, 21 (6-7) 519-22.

107. ADAMS H.W., MAINZ D.L., Eosinophilic ascites. A case report and review of the literature, Am. J. Dig. Dis., 1977, 22 (1) 40-2.

108. VANDEWIELE I.A., MAEYAERT B.M., VAN CUTSEM E.J., GEBOES K.R., KNOCKAERT D.C., Massive eosinophilic ascites: differential diagnosis between idiopathic hypereosinophilic syndrome and eosinophilic gastroenteritis, Acta Clin. Belg., 1991, 46 (1) 37-41.

109. MEHANNA D., NASEEM Z., MUSTAEV M., Eosinophilic cholecystitis with common bile duct stricture: a rare disease, BMJ Case Rep., 2016, p. bcr2016215694.

110. CASELLA G., VILLANACCI V., BASSOTTI G., Eosinophilic ascites resolution with ketotifen, Mayo Clin. Proc., 2011,86 (10) 1027.

111. ANIĆ B., CRKVENCIĆ N., MAYER M., Idiopathic eosinophilia with ascites (case report), Lijec. Vjesn., 123 (11-12) 308-12.

112. LEVESQUE H., ELIE-LEGRAND M.C., THOREL J.M., TOUCHAIS O., GANCEL A., HECKETSWEILLER P. et al., Idiopathic hypereosinophilic syndrome with predominant digestive manifestations or eosinophilic gastroenteritis? Apropos of 2 cases, Gastroenterol. Clin. Biol., 1990, 14 (6-7) 586-8. 
113. INOUE A., MICHITAKA K., SHIGEMATSU S., KONISHI I., HIROOKA M., HIASA Y. et al., Budd-Chiari syndrome associated with hypereosinophilic syndrome; a case report, Intern. Med., 2007., 46 (14) 1095-100.

114. LESUR G., TURNER L., BERNIER M., BERGEMER A.M., BERNADES P., DUPUY P., Eosinophilic ascites in cancer of the pancreas, Gastroenterol. Clin. Biol., 1995, 19 (3) 317-8.

115. KOBAYASHI T.K., MURAMATSU M., UEDA M., NISHINO T., BAMBA M., URABE M. et al., Eosinophilic ascites: taxolinduced hypersensitivity?, Cytopathology, 2004, 15 (3) 171-2.

116. RAKESH K., BANERJEE R., GUPTA R., RAMJI C., PRADEEP R., RAO G.V. et al., Eosinophilic pancreatitis with pseudocyst, Indian J. Gastroenterol., 26 (3) 136-7.

117. YOSHIKANE H., YATSUYA H., SAKAKIBARA A., HIDANO H., ARISAWA T., GOTO H., A case of eosinophilic peritonitis in which ascites interleukin 5 presented at a high level, Hepatogastroenterology, 47 (36) 1588-9.

118. MA S.K., KWONG Y.L., SHEK T.W., WAN T.S., CHOW E.Y., CHAN J.C. et al., The role of trisomy 8 in the pathogenesis of chronic eosinophilic leukemia, Hum. Pathol., 1999, 30 (7) 864-8.

119. IRIUCHISHIMA H., OGAWA Y., HOSHINO T., YOSHIDA T., SATO K., TAKAGI H. et al., Chronic eosinophilic leukemia with symptoms resembling Budd-Chiari syndrome due to liver infiltration, Rinsho. Ketsueki., 2007, 48 (6) 505-9.

120. ADEMA A.Y., SCHILDER A.M., SCHREUDER T.C.M.A., GRÜNBERG K., BULTINK I.E. M., MULDER C.J.J., Ascites as the presenting symptom in a patient with Churg-Strauss syndrome, J. Gastrointestin. Liver Dis., 2010, 19 (2) $199-201$.

121. TOKUNAGA M., YAMADA M., YOSHIKAWA S., KONDO A., MISHIMA M., INOUE S. et al., Systemic lupus erythematosus with marked eosinophilia and clinical features mimicking TAFRO syndrome, Rinsho. Ketsueki., 2018, 59 (6) 688-694.

122. SON K.H., KWAK J.J., PARK J.O., A case of cytomegalovirus-negative Ménétrier's disease with eosinophilia in a child, Korean J. Pediatr., 2012, 55 (8) 293-6.

123. YAMAGUCHI K., NAITOH S., NOMURA S., A case of malignant mesothelioma of the pleura and the peritoneum detected by sudden onset of back pain and pleural effusion and ascites," Nihon Kyobu Shikkan Gakkai Zasshi, 1997, 35 (9) 996-1002.

124. SIDERITS R., GODYN J., TUFANKJIAN D., OUATTARA O., T-cell lymphoproliferative disorder of hand-mirror cell morphology presenting in an eosinophilic loculated peritoneal effusion, with omental "caking, Cytojournal, 2006, 3, p. 13.

125. FATIMI S.H., DEEDAR-ALI-KHAWAJA R., Catamenial pneumothorax associated with ascites, eosinophilic pleural effusion, and relatively low glucose content, Am. Surg., 2010, 76 (11) E212-3.

126. ROWLANDS C.G., Cytology of ascitic fluid in a patient with granulocytic sarcoma (extramedullary myeloid tumor). A case report, Acta Cytol., 43 (2) 227-31.

127. BITAR E., RIZK A., NASR W., GÉDÉON E.M., TABBARA W., Familial paroxysmal polyserositis. Previously unpublished peritoneal complications. A case, Presse Med., 1985, 14 (10) 586-8.

128. ROWLAND M., BROWN R.B., GOLDMAN M., Eosinophilic peritonitis: an unusual manifestation of spontaneous bacterial peritonitis, J. Clin. Gastroenterol., 1985, 7 (4) 369-71.

129. SILVERMAN J.F., Extramedullary hematopoietic ascitic fluid cytology in myelofibrosis, Am. J. Clin. Pathol., 1985,84 (1) 125-8.

130. ALHMOUD T., HANSON J.A., PARASHER G., Eosinophilic gastroenteritis: an underdiagnosed condition, Dig. Dis. Sci., 2016, 61 (9) 2585-92.

131. CHANG J.Y., CHOUNG R.S., LEE R.M., LOCKE G.R. 3rd, SCHLECK C.D., ZINSMEISTER A.R. et al., A shift in the clinical spectrum of eosinophilic gastroenteritis toward the mucosal disease type, Clin. Gastroenterol. Hepatol., 2010, 8 (8) 669-75; quiz e88.

132. TALLEY N.J., SHORTER R.G., PHILLIPS S.F., ZINSMEISTER A.R., Eosinophilic gastroenteritis: a clinicopathological study of patients with disease of the mucosa, muscle layer, and subserosal tissues, Gut, 1990, 31 (1) 54-8.

133. LIU L., LIANG X.Y., HE H., HUANG H., JIA L.P., Clinical features of eosinophilic gastroenteritis with ascites, Z. Gastroenterol., 2013, 51 (7) 638-42.

134. TENG X., XU L., WU J., SUN M., GUO J., MAO Z., Clinical and morphological features of serosal form of eosinophilic gastroenteritis in a retrospective study of 10 children, Fetal Pediatr. Pathol., 2013, 32 (4) 276-83.

135. SAVINO A., SALVATORE R., CAFAROTTI A., CECAMORE C., DE SANCTIS S., ANGELUCCI D. et al., Role of ultrasonography in the diagnosis and follow-up of pediatric eosinophilic gastroenteritis: a case report and review of the literature, Ultraschall Med., 2011, 32 (S 02) E57-62, Suppl 2.

136. MAÀMOURI N., GUELLOUZ S., BELKAHLA N., MOHSNI B., NAIJA N., CHOUAIB S. et al., Eosinophilic gastroenteritis, La Rev. Med. interne, 2012, 33 (8) 421-5.

137.HAN X.X., GUAN D.X., ZHOU J., YU F.H., WANG G.L., MEI T.L. et al., Clinical analysis of eosinophilic gastroenteritis in 71 children, Zhonghua er ke za zhi = Chinese J. Pediatr., 2018, 56 (7) 500-504.

138. SHEN H., Clinical analysis of eosinophilic gastroenteritis in six children, Zhonghua er ke za zhi = Chinese J. Pediatr., 2010,48 (8) 614-6.

139. CHEN M.-J., CHU C.-H., LIN S.-C., SHIH S.-C., WANG T.-E., Eosinophilic gastroenteritis: clinical experience with 15 patients, World J. Gastroenterol., 2003, 9 (2) 2813-6.

140. JEON E.J., LEE K.M., JUNG D.Y., KIM T.H., JI J.S., KIM H.K. et al., Clinical characteristics of 17 cases of eosinophilic gastroenteritis, Korean J. Gastroenterol., 2010, 55 (6) 361-7.

141. HARMON W.A., HELMAN C.A., Eosinophilic gastroenteritis and ascites, J. Clin. Gastroenterol., 1981, 3 (4) $371-3$.

142. KIM N.I., JO Y.J., SONG M.H., KIM S.H., KIM T.H., PARK Y.S. et al., Clinical features of eosinophilic gastroenteritis, Korean J. Gastroenterol., 2004, 44 (4) 217-23.

143.LIU Q., ZHANG H., ZHAO Y.M., ZHOU L.L., GAO B.H., CHEN Y.P., Clinical, pathologic and radiologic analysis of paragonimiasis in children, Zhonghua bing li xue za zhi = Chinese J. Pathol., 2017, 46 (2) 108-111.

144. CHI J.G., CHOI W.Y., LEE O.R., CHUNG C.S., Changes of liver and diaphragm in experimental paragonimiasis, Kisaengchunghak. Chapchi., 1982, 20 (2) 160-168. 
145. HAYDEN D.W., KRUININGEN H J., Experimentally induced canine toxocariasis: laboratory examinations and pathologic changes, with emphasis on the gastrointestinal tract, Am. J. Vet. Res., 1975, 36 (11) 1605-14.

146. TOLONE G., BRAI M., BONASERA L., BELLAVIA A., PONTIERI G.M., Role of mast cells and eosinophils in tissue injury caused by injection of Ascaris fluid in the rat, Pathol. Microbiol. (Basel)., 1972, 38 (3) 192-9.

147. SPECHT D., WIDMER E.A., Response of mouse liver to infection with tetrathyridia of Mesocestoides (Cestoda), J. Parasitol., 1972, 58 (3) 431-7.

148. RAMDIAL P.K., HLATSHWAYO N.H., SINGH B., Strongyloides stercoralis mesenteric lymphadenopathy: clue to the etiopathogenesis of intestinal pseudo-obstruction in HIV-infected patients, Ann. Diagn. Pathol., 2006, 10 (4) $209-14$.

149. OKUMURA K., KUBOTA T., LEFOR A.K., SAITO A., MIZOKAMI K., Increased number of eosinophils in ascites is associated with intestinal anisakidosis, J. Helminthol., 2018, pp. 1-4.

150. SHIRAHAMA M., KOGA T., ISHIBASHI H., UCHIDA S., OHTA Y., SHIMODA Y., Intestinal anisakiasis: US in diagnosis, Radiology, 1992, 185 (3) 789-93.

151. WALKER N.I., CROESE J., CLOUSTON A.D., PARRY M., LOUKAS A., PROCIV P., Eosinophilic enteritis in northeastern Australia. Pathology, association with Ancylostoma caninum, and implications, Am. J. Surg. Pathol., 1995, 19 (3) $328-37$.

152. LAAKSONEN S., KUUSELA J., NIKANDER S., NYLUND M., OKSANEN A., Outbreak of parasitic peritonitis in reindeer in Finland, Vet. Rec., 2007, 160 (24) 835-41.

153. BAI Y., QIAO W.G., ZHU H.M., HE Q., WANG N., CAI J.Q. et al., Role of transgastric natural orifice transluminal endoscopic surgery in the diagnosis of ascites of unknown origin (with videos), Gastrointest. Endosc., 2014, 80 (5) $807-16$.

154. WANG S.S. LEE F.Y., CHAO Y., CHEN C.C., LIN H.Y., WU S.L. et al., Clinical significance of complements in ascitic diseases: elevated complement levels disapproving the liver disease origin, Proc. Natl. Sci. Counc. Repub. China. B., 1996, 20 (2) $51-7$.

155. WANG Q., LU C.-M., GUO T., QIAN J.-M., Eosinophilia associated with chronic pancreatitis, Pancreas, 2009, 38( 2) 149-53.

156. TOKOO M., OGUCHI H., KAWA S., HOMMA T., NAGATA A., Eosinophilia associated with chronic pancreatitis: an analysis of 122 patients with definite chronic pancreatitis, Am. J. Gastroenterol., 1992, 87 (4) 455-60.

157. KLEIN N.C., HARGROVE R.L., SLEISENGER M.H., JEFFRIES G.H., Eosinophilic gastroenteritis, Medicine (Baltimore)., 1970, 49 (4) 299-319.

158. KURTZ J.M., RUSSELL S.W., LEE J.C., SLAUSON D.O., SCHECHTER R.D., Naturally occurring canine glomerulonephritis, Am. J. Pathol., 1972, 67 (3) 471-82.

159.ZHENG X., CHENG J., PAN K., YANG K., WANG H., WU E., Eosinophilic enteritis: CT features, Abdom. Imaging, 33 (2) 191-5.

160. OKUDA K., DAIMON Y., IWASE T., MITSUFUJI S., Novel findings of capsule endoscopy and double-balloon enteroscopy in a case of eosinophilic gastroenteritis, Clin. J. Gastroenterol., 2013, 6 (1) 16-9.

161. DURIEU I., NOVE-JOSSERAND R., CATHEBRAS P., DURAND D.V, ROUSSET H., LEVRAT R., Eosinophilic ascites. 2 new case reports, La Rev. Med. interne, 1992, 13 (6) 446-8.

162. MIHĂILESCU E., MICU D., Eosinophilia in the pleural and peritoneal effusions, Med. Interne, 23 (3) 191-4.

163. TAN A.C., KRUIMEL J.W., NABER T.H., Eosinophilic gastroenteritis treated with non-enteric-coated budesonide tablets, Eur. J. Gastroenterol. Hepatol., 2001, 13 (4) 425-7.

Received December 12, 2018 